\title{
Monitoring of precipitation process in AZ31 and AZ91 magnesium alloys by internal damping measurement
}

Andrea Soviarová ${ }^{1}$, Peter Palček ${ }^{1}$, Zuzanka Trojanová ${ }^{2}$

${ }^{1}$ University of Žilina, Faculty of Mechanical Engineering, Department of Material Engineering, Univerzitná 8215/1, 010 26 Žilina, Slovakia. E-mail: andrea.soviarova@fstroj.uniza.sk, peter.palcek@fstroj.uniza.sk

${ }^{2}$ Charles University in Prague, Faculty of Mathematics and Physics, Department of Physics of Materials, Ke Karlovu 5, 12116 Praha 2, Czech Republic. E-mail: ztrojan@met.mff.cuni.cz

Internal damping is able to monitor the microstructural changes in solid materials and these changes can be based onvarious mechanisms. In this investigation a same heat treatment was carried out on AZ31 and AZ91 magnesium alloys, aimed at detection of microstructure changes of material after homogenization annealing and also the process of precipitation was continuously analyzed by the internal damping measurement. Internal damping was measured as a function of temperature in AZ31 and AZ91 magnesium alloys by ultrasonic resonance spectroscopy. The internal damping spectrum was measured in the temperature range from $50{ }^{\circ} \mathrm{C}$ up-to $390{ }^{\circ} \mathrm{C}$. Peaks of internal damping occurred in temperature range from $250{ }^{\circ} \mathrm{C}$ up-to $350{ }^{\circ} \mathrm{C}$ on AZ91 magnesium alloy. Also the mictrostructure analysis was carried out at the diferent stages of the internal damping measurement which showed creation of continuous precipitate in the maximum of the internal damping peak. The creation of the peak is caused by absorbation of energy by the process of continuous precipate nucleation and growth in the volume of material grains.

Keywords: Internal Damping, Magnesium Alloy, Continuous Precipitate

\section{Acknowledgement}

This work has been supported by Scientific Grant Agency of Ministry of Education of Slovak Republic and Slovak Academy of Sciences $N^{0} 1 / 0797 / 12$ and project SK-PL-0083-12.

\section{References}

[1] AVEDESIAN M. M., BAKER, H. (1999). Magnesium and Magnesium Alloys. In Materials Park OH:ASM International, 1999. 298 s. ISBN 0-87170-657-1.

[2] BLANTNER M. S. ET AL. (2007). Internal Friction in Metallic Materials. Berlin Heidelberg: OSpringer -Verlag, 2007, p. 539, ISBN 3-540-68757-2.

[3] BLAŽEK D., PALČEK P. (2011). Internal friction use in monitoring the degradation processes in a material, Materials Engineering - Materiálové inžinierstvo 18 (2011) 145-150, ISSN 1335 - 0803

[4] BLAŽEK D. (2012). Analýza spektra vnútorného tlmenia horčíkových zliatin, (Analysis of internal friction spectra of magnesium alloys) [Dissertation thesis], University of Žilina, Žilina, 2012 (in Slovak)

[5] HLAVÁČOVÁ, I., PALČEK, P., CHALUPOVÁ, M., DRESSLEROVÁ, Z. (2013). Plastic Deformation Properties of Magnesium Alloy AZ61. Manufacturing Technology, vol. 13, pp. 313 - 319. ISSN 1213-2489.

[6] LIU S., JIANG H., LI X., RONG, L. (2010). Effect of precipitation on internal friction of AZ91 magnesium alloy, In Trans. Nonferrous Met. Soc. China 20, 2010, p. 453-457

[7] PALČEK P., SOVIAROVÁ A., TROJANOVÁ Z. (2014). Internal friction as a function of temperature in magnesium alloy. In:18 ${ }^{\text {th }}$ Workshop on Advances in Experimental Mechanics 2014 (IWAEM) August 18-22, 2014 in Portorož, Slovenia 18th, , Center for Experimental Mechanics, Faculty of Mechanical Engineering, 2014. (in press)

[8] POLMEAR I. J. (2006). Light Alloys Light Alloys Fourth edition 2006, p. 421 ISBN 0750663715

[9] SCHALLER R., FANTOZZI G., GREMAUD G. Mechanical spectroscopy $Q^{-1} 2001$ with applications to materials science. Switzerland Trans Tech Publications, 683p. ISBN 0-87849-876-1

[10] SERAK J., VODEROVA M., VOJTECH D., NOVAK P. (2014). Microstructure and Properties of Magnesium Alloys Working at Elevated Temperatures. In Manufacturing Technology June 2014, Vol. 14, No. 2, p. 238-244 ISSN 1213-2489,

[11] R.G LEISURE, K. FOSTER, J.E. HIGHTOWER, D.S AGOSTA,. (2007). Internal friction studies by resonant ultrasound spectroscopy, In Materials Science and Engineering A, 370 (2004) pp. 34-40

[12] ZHENYAN ZHANG, XIAOQIN ZENG, WENJIANG DING. (2005).The influence of heat treatment on damping response of AZ91D magnesium alloy. Materials science and Enginering A 392 (2005) p.150 - 155 